
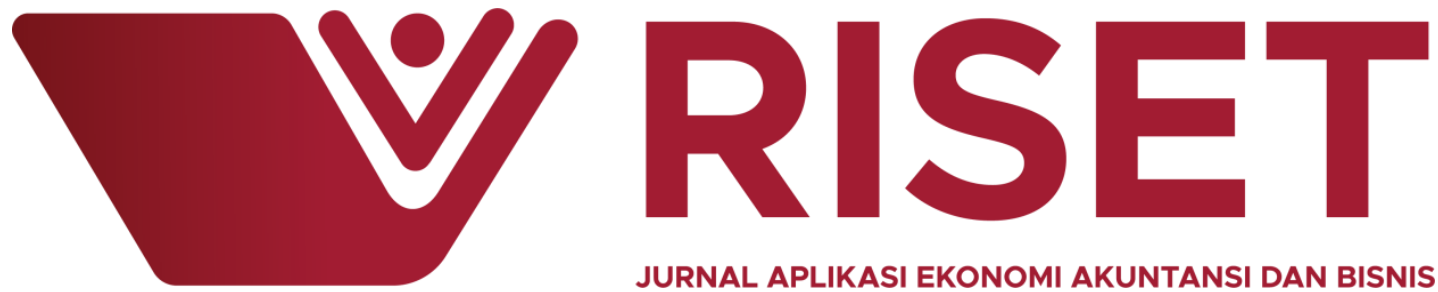

JURNAL APLIKASI EKONOMI AKUNTANSI DAN BISNIS

\title{
Factors Affecting Capital Structure And Stock Prices Of Agricultural And Mining Companies
}

\author{
Ivena Gracia $^{1)}$ Rosinta Ria Panggabean ${ }^{2)}$ \\ 1.2.) Bina Nusantara University
}

\section{INFO ARTIKEL}

Factors Affecting Capital Structure And Stock Prices Of Agricultural And Mining Companies

Submitted:

14 - April - 2019

Revised:

14 - Juli - 2019

Accepted:

16 - Juli - 2019

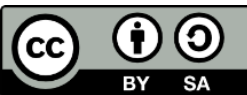

\begin{abstract}
The purpose of this study was to analyze the influence of business risk, asset growth, sales growth, earning per share, and asset structure to capital structure and share price.

This study involved mining and agriculture companies listed on IDX within the period of 2010-2017. The analysis employed eViews 9.

Based on the hypothesis testing, it was found that that business risk, sales growth, and asset structure do not have a significant effect on capital structure. However, asset growth has a significant influence. Furthermore, sales growth and EPS do not have a significant effect on share price, but the asset structure has a significant influence.

This research is a development of previous research by adding earnings per share as an independent variable and covering the period 2010 - 2017 in order to show the most actual conditions.

Company management can make the results of this study a consideration in determining the optimal capital structure.

This study only examined the mining and agricultural sectors on the Indonesian stock exchange.
\end{abstract}

Keywords: Business Risk, Asset Growth, Sales Growth, EPS, Asset Structure, Capital Structure, Share Price.

\section{INTRODUCTION}

A country's economic progress is reflected by the existing capital market activities in the country (Coşkun et al., 2017). As a developing market (emerging market), stock price movements in the Indonesian capital market fluctuate relatively high (Suryanta, 2014). In other words, changes in stock prices reflect changes in investors' interests in these shares. 
These conditions are influenced by several factors; one of which is information from external parties, such as stock rankings, current trends, and others.

The movement of the stock price index is closely related to the strength of demand and supply of shares. According to (Ratih, Apriatni, \& Saryadi, 2013), changes in stock is caused by instantaneous appraisals of sellers and buyers, which are influenced by many factors. Factors that can influence stock prices include the deposit interest rate, the company's financial condition known from the company's financial statements, inflation rate, the number of profits earned by the company, marketing strategies, level of risk and returns.

To finance company assets, a capital structure related to the amount of debt and equity is needed (Kakilli Acaravci, 2015). One important thing which needs to be done regarding the capital structure is increasing public knowledge in the field of capital markets and the availability of funds from potential investors who are interested in investing their capital. This is related to the risk and income that will be received. Investors will conduct various analyses related to their decisions to invest their capital in the company by paying attention to information; one of the sources of information is the company's financial statements.

According to information from www.kontan.co.id, the stock price of mining companies will potentially increase in 2018. When the Composite Stock Price Index (CSPI) was corrected, the share price of mining companies actually showed positive performance. Compared to the stock prices of the other sectors that fell, the share prices of mining companies increased by $0.85 \%$, while year-to-date prices of mining stocks increased by $10.65 \%$. The increase in the performance of the mining sector is in line with the increasing commodity prices so that the mining issuers can obtain high income.

In addition to the mining sector, the agricultural sector also shows projections in a positive direction. According to recent information from Price Waterhouse Cooper (PWC) after releasing its annual report for 2017, there are several key sectors that play an important role in achieving balance in economic progress (PWC, 2017) One of them is agricultural sector. This sector plays an important role because agricultural commodities are the main source of life needs. Even most of the global workforce in agriculture (more than 90\%) is still in developing countries.

Many factors influence the capital structure, including business risk, asset growth, sales growth, earnings per share (EPS), and asset structure. The decision to finance a company will determine the ability of the company to carry out its operations. Business risk is the uncertainty of revenue received by a company due to the nature of the business carried out by the company. Based on the trade-off theory, companies with small business risks can use debt to enlarge the companies. Conversely, the risks of large businesses will result in the cost of financial difficulties that will not offset the cost of tax savings (Ferdiansyah \& Isnurhadi, 2013). A company that has a high risk will experience difficulties in finding external funds. Thus, it can be concluded that the higher the risk faced by the company, the company tends to have less debt (Kartika, 2009).

Business risk has a close relationship with the capital structure where companies with large business risks must use less debt than companies that have small business risks, because the greater the business risk, the greater use of debt will increase the interest expense so that it will further complicate the companies' finances. Debt is one of the external funds in the 
capital structure. The more debt, the higher the business risk borne by the company (Baker \& Martin, 2011)

Asset growth is an illustration of the company placing funds for operating and investment activities. To increase assets owned by the company, both current assets and fixed assets require funds. The funds can be obtained through internal funds or external funds. When retained earnings, which are sources of internal funds, have been exhausted, the company can make loans in the form of debt to creditors.

The stock price index is an indicator that shows stock price movements. One analytical tool for assessing stock prices is the company's fundamental analysis through an analysis of its financial ratios (Purnamasari, 2015). Earnings per Share (EPS) shows a comparison between the number of net profits obtained by investors or shareholders and the number of shares. The higher the EPS value, the greater the shareholders' profits the company will obtain.

Growing opportunities explain the prospects for future company growth. A company that has the opportunity to grow bigger will face an information gap between the manager and the shareholders regarding the quality of the project in which the company invested. This difference of information causes high capital for equity compared to capital for loans (Wimelda \& Marlinah, 2013).

The company's skills in generating profit for outstanding shares can be seen in the ratio of Earning per Share (EPS). An investor who invests in a company will receive a return on his shares. The higher earnings per share (EPS) given by the company will provide a pretty good return. This will encourage investors to make a bigger investment so that the company's stock price will continue to increase. Limits in the acquisition of debt and income based on interest result in a stable net profit after interest and taxes from EPS. With a stable profit and a number of outstanding shares considered constant, EPS will increase.

A company's assets can be divided into current assets and fixed assets. Comparison of the two assets determines the company's wealth or asset structure (Sebayang \& Putra, 2013). Asset structure is one of the most important parts in determining to fund in the company. Assets are guarantees that are considered by creditors when they provide loans to companies. The high asset structure makes creditors feel safer in providing loans. If the company is unable to pay the loan to the creditor, it is expected that the company's assets can cover the debt.

\section{LITERATURE REVIEW}

The Pecking Order Theory begins with an asymmetric assumption of managers who have information than outside investors about the company's prospects and profitability (MYERS, 1984). This information affects the choice between internal and external financing. The main principle of the Pecking Order Theory is that companies will be more likely to use internal funding sources, such as retained earnings, rather than external funds for funding activities. Except when the companies do not have sufficient internal funds, then the companies use debt (external) to meet the companies' funding decisions. With large retained earnings, the company will use retained earnings before deciding to use debt. 
Trade-off theory discusses the relationship between capital structure and firm value (Ghazouani, 2013). The trade-off model proposes that companies with large amounts of assets tend to use their own capital in their capital structure. Trade off-theory explains that the use of $100 \%$ debt is difficult to find in practice. In fact, the bigger the amount of debt, the higher the burden that must be borne by the company, including bankruptcy fees, agency fees, increasing interest expenses, and so on. Therefore, this theory states that the optimal capital structure is achieved when the balance between benefits and debt sacrifice occurs.

Capital structure is an arrangement or comparison between its own capital and long-term loans; so, the capital structure is part of the financial structure (Kesuma, 2009). (Pahuja \& Sahi, 2012) said that determining the optimal capital structure is to balance the risks and benefits achieved in achieving the goal of maximizing stock prices.

The company's stock price reflects the value of the company. To maximize the value of the company, it is also important to pay attention to financial claims. Relevant and adequate information is needed by investors to analyze and select stocks through the company's financial statements, especially the company's capital structure (Nurmalasari, 2009). If the company achieves good performance, the company's shares will be in great demand by investors. Good achievements achieved by the company can be seen in the company's financial statements.

\section{Hypothesis Development}

(Indrajaya, Herlina, \& Setiadi, 2011) Conduct research to analyze variables that influence capital structure. This study used five independent variables, namely, asset structure, company size, growth rate, profitability, and business risk. The study found that business risk variables did not significantly influence capital structure. However, the asset growth variable has a positive influence on the capital structure. The company's asset growth shows the number of funds allocated by the company to its assets.

(Badruzaman, 2017) Found that Earning per Share (EPS) has a positive effect on the stock prices of basic industries and chemicals in the Indonesia Stock Exchange. Applying the pecking order theory, developing companies will tend to use external funds to finance growth.

(Insiroh, 2014) I used the variables of profitability, company size, asset growth, and asset structure. The sample was taken from 23 Real Estate and Property companies listed on the IDX for the 2008-2013 period using purposive sampling method. The results of the study revealed that asset structure variables have a significant and negative effect on the capital structure. This indicates that the real estate and property industry companies mostly invest in fixed assets and will prioritize the fulfillment of funds from their own capital while the debt is only as a compliment.

The level of the business risk of a company is influenced by the stability of revenue and the structure of its operating costs. In addition, business risk can occur if the company has a debt that is too high. This is because the company is deemed necessary to provide sufficient amounts of funds to prepare for repayment of its debts and the interest expense borne by the company. Based on the trade-off theory, a company with a large business risk must use a smaller debt that a company that has a low business risk. 
Ivena Gracial ${ }^{1)}$ Rosinta Ria Panggabean ${ }^{2)}$ Factors Affecting Capital Structure And Stock Prices Of Agricultural And Mining Companies

Research by (Indrajaya et al., 2011) found that business risk does not significantly influence capital structure. (Wardana \& Sudiartha, 2015) Found that business risk has a significant positive influence on the capital structure. Based on the results of several previous studies, there were inconsistencies in this variable. So, the first hypothesis in this study is:

HA1: Business risk has an influence on the capital structure of mining and agricultural companies.

An increase in assets will attract creditors to provide loans to companies. The greater the growth of the company's assets, the more the company uses its own capital derived from retained earnings, in accordance with the Pecking Order Theory. (Margaretha \& Ramadhan, 2010) Stated that asset growth affects both capital structure models, namely total leverage and short-term leverage. However, growth does not have an influence on the capital structure model in the long-term leverage model. (Insiroh, 2014) Stated that asset growth has a significant and negative influence on the capital structure. Thus, the second hypothesis of this study is:

HA2: Asset growth has an influence on the capital structure of mining and agricultural companies.

A high level of sales will encourage companies to increase capital to increase sales. Companies that want to develop business activities and expand market share will require large funds. If internal funds do not meet the expansion needs, the companies must seek additional funds to meet these needs.

(Amjed \& Shah, 2016) Found that sales growth had a non-significant positive effect on the capital structure. Companies that have stable sales growth rates are relatively more noticed and more attractive to investors. With a stable sales growth rate, the tendency of companies to use debt as a source of funding becomes smaller. This minimizes the risk of bankruptcy. So, the hypothesis for the effect of sales growth on capital structure and stock prices is as follows:

HA3: Sales growth has an influence on the capital structure of mining and agricultural companies.

HA5: Sales growth has an influence on stock prices of mining and agricultural companies.

In making investment decisions, the number of earnings per share can be used as a basis for decision making by investors to invest (Badruzaman, 2017). (Datu \& Maredesa, 2017) Found that EPS has a positive and significant influence on stock prices. So, the following hypothesis is formulated:

HA6: EPS has an influence on stock prices of mining and agricultural companies.

(Insiroh, 2014) the research found that asset structure has a significant and negative influence on capital structure. (Zhang, 2010) states that profitability, firm size, firm age, and tangible assets have a positive effect on capital structure, while growth has a negative effect on capital structure.

According to the trade-off theory, the structure of assets will have an influence on the capital structure and stock price. The larger the number of assets, the greater the loan or 
debt that the company will get. Also, the greater the value of the company's assets, the higher the possibility of investors to invest in the company. Thus, the hypothesis for the influence of the Asset Structure on the capital structure and stock price is as follows:

HA4: The structure of assets has an influence on the capital structure of mining and agricultural companies.

HA7: The structure of assets has an influence on stock prices of mining and agricultural companies.

\section{RESEARCH METHODS}

The samples of this study were selected using purposive sampling method. The criteria used in sample selection are:

1. Agriculture and Mining Companies listed on the Indonesia Stock Exchange (IDX) within the period 2010-2017.

2. Companies that consistently use currency units.

3. Companies that publish financial statements during the observation period from 20102017.

4. Companies that have not suffered from EBIT losses during the study period.

5. Companies whose variables do not experience abnormal changes.

Table 1. Sample Selection

Agriculture and Mining Companies listed on the Indonesia Stock Exchange (IDX) within the period 55 2010-2017

\begin{tabular}{lc}
\hline Companies that are inconsistent in the use of currency units & $(7)$ \\
\hline Companies that do not publish financial statements during the observation period from 2010-2017 & $(30)$ \\
\hline Loss on EBIT during the study period & $(7)$ \\
\hline Companies whose variables experience abnormal changes & 10 \\
\hline Total sample companies & 80 \\
\hline Total research sample (10 x 8 years) & 11 \\
\hline Source: Data processing results
\end{tabular}

This study used descriptive statistics as a method of analysis. This study used the classic assumption test, including normality test, multicollinearity test, heteroscedasticity test, and autocorrelation test. To determine the model which will be chosen, the Chow test was used, followed by the Hausman Test and the Lagrange Multiplier Test. Then, the Random Model from some of the tests was obtained.

In addition, this study used panel data regression analysis. This study employed several statistical tests, namely descriptive statistic, Goodness of fit testing (T-Test), and logistic regression analysis which includes determination coefficient test, partial coefficient test, and simultaneous testing. The general equation of multiple linear regression is used for the independent variables of the general non-independent variables of multiple regression:

$$
\begin{aligned}
& \text { CAPSTRU }=\alpha+\beta 1 \text { BRISK }+\beta 2 \text { AGROW }+\beta 3 \text { SGROW }+\beta 5 \text { ASTRU }+€ \\
& \text { PRICE }=\alpha+\beta 3 \text { SGROW }+\beta 4 \text { EPS }+\beta 5 \text { ASTRU }+€
\end{aligned}
$$


Where:

$\begin{array}{ll}\text { CAPSTRU } & =\text { Capital Structure } \\ \text { PRICE } & =\text { Share price } \\ \alpha & =\text { Constants } \\ \beta & =\text { Estimation of the regression coefficient } \\ \text { BRISK } & =\text { Business Risk } \\ \text { AGROW } & =\text { Asset Growth } \\ \text { SGROW } & =\text { Sales Growth } \\ \text { EPS } & =\text { Earnings Per Share } \\ \text { ASTRU } & =\text { Asset Structure } \\ € & =\text { Residual Variable (error rate) }\end{array}$

\section{OPERATIONALIZATION OF VARIABLES}

Capital Structure

Stock price

$$
\text { Capital Structure }=\frac{\text { Total Long Term Debt }}{\text { Equity }}
$$

Share Price is the nominal value of closing (closing price).

Business Risk

BRISK $=\frac{\sigma E B I T}{\text { TOTALASSETS }}$

Assets Growth

Growth of Assets $=\frac{\text { Total Assets }_{t}-\text { Total Assets }_{t-1}}{\text { Total Assets }_{t-1}}$

Sales Growth

Growth of Sales $=\frac{s_{t}-S_{t-1}}{s_{t-1}} \times 100 \%$

Earning Per Share

Assets Structure

$$
E P S=\frac{\text { Net Income }}{\text { Shares }}
$$

$$
\text { Assets Structure }=\frac{\text { Fixed Assets }}{\text { Total Assets }} \times 100 \%
$$

\section{RESULTS AND DISCUSSION}

This qualitative research employed secondary data obtained from the website of the Indonesia Stock Exchange (IDX), www.idx.co.id. The author took companies from the mining and agricultural industry listed on the Indonesia Stock Exchange for 8 consecutive years, starting from 2010-2017.

The Chow test results of the redundant fixed-effect or likelihood ratio for this model have a value of section $\mathrm{F}$ and cross-section chi-square of 0.0000 and 0.000 . The probability value is smaller than the significant level $(\alpha=0.05)$. So, it can be concluded that estimates that are better used in this model are fixed effects. According to the Hausman test results, Prob 
values are 0.1199 and 0.7319 . The prob values 0.1199 and $0.7319>0.05$. Thus, the model suitable for testing is the Random Effect model. Based on the results of the Chow Test and the Hausman Test, the suitable model still cannot be determined. Therefore, the LM test needed to be conducted. The LM test results are based on chi-squares distribution with a degree of freedom equal to the number of independent variables. Statistical values are 18.40951 and 36.17195, and the value of the chi-square for each test is 0.0000 , meaning that the estimation used in panel data regression is the Random Effect method.

Based on Normality test results, the Jarque-Bera - CAPSTRU value is 27.10559 , and the Jarque-Bera - PRICE value is 43.78164. The Jarque-Bera value $>X^{\wedge} 2$ or greater than 2. Then, the data were not normally distributed. Then, the p-value - CAPSTRU is 0.000001 where $<0.05$, and the p-value - PRICE is 0.000000 where $<0.05$, meaning that the data were not normally distributed. Based on Multicollinearity test, the results of the calculation of the multicollinearity test illustrated the absence of the correlation matrix value above or> 0.90. If the correlation matrix does not have a value> 0.90 , there is no serious multicollinearity in the model. Based on Heteroscedasticity test results, it can be seen that the probability value is greater than $\alpha=5 \%$. So it can be concluded that the research data is free from heteroscedasticity problems. So it can be concluded that research data is free from heteroscedasticity problems. Based on Autocorrelation test results, the probability value obtained from the autocorrelation test was $<5 \%(0.0000<0.05)$. This indicates that the study contains autocorrelation. According to (Basuki \& Prawoto, 2016): 297), in time series data, there will be autocorrelation.

Table 2. F-test Result Analysis for Capital Structure and Share Price

\begin{tabular}{ll}
\hline F-statistic - CAPSTRU & 3.139556 \\
\hline Prob(F-statistic) - CAPSTRU & 0.019204 \\
\hline F-statistic - PRICE & 1.682290 \\
\hline Prob(F-statistic) - PRICE & 0.177888 \\
\hline Source: Data processing results &
\end{tabular}

As Table 2 shows, the value of the F - CAPSTRU test is $0.019204<a(5 \%)$. It can be seen that the independent variables can simultaneously affect the dependent variable CAPSTRU. The value of the F - PRICE test is $0.177888>$ a $(5 \%)$. It can be seen that simultaneously, the independent variables cannot affect the dependent variable - PRICE.

Table 3. Adjusted R-squared Results Analysis for Capital Structure and Share Price

\begin{tabular}{ll}
\hline R-squared - CAPSTRU & 0.143427 \\
\hline Adjusted R-squared - CAPSTRU & 0.097743 \\
\hline R-squared - PRICE & 0.062271 \\
\hline Adjusted R-squared - PRICE & 0.025255 \\
\hline Source: Data processing results
\end{tabular}

Table 3 shows that the value of the Adjusted R-square - CAPSTRU test was 0.097 with $9.7 \%$ interpretation. The variation of the dependent variable can be explained by the independent variable, and the remaining $90.3 \%$ of the dependent variable is explained by other variables outside the model used as a model. It shows that the value of the Adjusted R-square - PRICE test was 0.025 , having an interpretation of $2.5 \%$. The variation of the 
Ivena Gracial ${ }^{1)}$ Rosinta Ria Panggabean ${ }^{2)}$ Factors Affecting Capital Structure And Stock Prices Of Agricultural And Mining Companies

dependent variable can be explained by the independent variable, and the remaining $97.5 \%$ of the dependent variable is explained by other variables outside the model used as a model.

Table 4. Panel Data Regression Result Analysis for Capital Structure

\begin{tabular}{lllll}
\hline \multicolumn{1}{c}{ Variable } & \multicolumn{1}{c}{ Coefficient } & \multicolumn{1}{c}{ Std. Error } & t-Statistic & Prob. \\
\hline BRISK & 0.003970 & 0.004206 & 0.943965 & 0.3482 \\
\hline AGROW & 0.328658 & 0.100830 & 3.259534 & 0.0017 \\
\hline SGROW & -0.000155 & 0.000897 & -0.173071 & 0.8631 \\
\hline ASTRU & 0.000566 & 0.000325 & 1.741227 & 0.0857 \\
\hline C & 0.449318 & 0.081071 & 5.542311 & 0.0000 \\
\hline R-squared & & & 0.143427 & \\
\hline Adjusted R-squared & & 0.097743 & \\
\hline F-statistic & & 3.139556 & \\
\hline Prob(F-statistic) & & 0.019204 & \\
\hline
\end{tabular}

Table 5. Panel Data Regression Result Analysis for Share Price

\begin{tabular}{lllll}
\hline \multicolumn{1}{c}{ Variable } & \multicolumn{1}{c}{ Coefficient } & Std. Error & \multicolumn{1}{c}{ t-Statistic } & Prob. \\
\hline SGROW & -1.305481 & 1.653784 & -0.789390 & 0.4323 \\
\hline EPS & 0.260476 & 3.430948 & 0.075920 & 0.9397 \\
\hline ASTRU & -1.281548 & 0.617280 & -2.076123 & 0.0413 \\
\hline C & 937.8532 & 303.1316 & 3.093882 & 0.0028 \\
\hline R-squared & & & 0.062271 & \\
\hline Adjusted R-squared & & & 0.025255 & \\
\hline F-statistic & & & 1.682290 & \\
\hline Prob(F-statistic) & & & 0.177888 & \\
\hline
\end{tabular}

Source: Data processing results

The testing of hypothesis 1 in table 4 is used to examine whether the business risk variables affect the capital structure of agricultural and mining companies listed on the Indonesia Stock Exchange within the period of 2010-2017. The test results for business risk variables have a profitability value of $0.3482>0.05$. So, HA1 is rejected. The results in table 20 also show that $\mathrm{t}$-statistics < $\mathrm{t}$-table is $0.943965<1.99300$. This means that $\mathrm{H} 1$ is rejected, where the business risk does not affect the capital structure.

This is because investors have the idea that companies that have a high level of risk will also provide high returns. Mining has high growth potential and a high level of risk. These investors' thoughts are in line with the Trade-off Theory which states that a higher risk due to the enlargement of debt tends to reduce the stock price; however, it will increase the rate of return of expectations for the price of the expectation. This research is not in line with the research by (Mohammed, 2012) and (Alnajjar, 2015), which shows that business risk was considered when the decision of a firm's capital structure made.

The test results for asset growth variables in Table 4 (AGROW) indicate that the asset growth variables have a coefficient of 0.328658 . This shows that the influence is positive. The value probability is $0.0017<0.05$. Thus, it can be concluded that asset growth variables have a significant positive effect on asset structure. In addition, t-statistics <t-table is 3.259534> 1.99300. So, H2 is accepted as asset growth does not affect the capital structure. This research is in line with the research by (Insiroh, 2014). According to (Insiroh, 2014), changes in the increase or decrease of assets will not have an influence on the manager's 
decision in choosing funding decisions for the company. The company's asset growth shows the number of funds allocated by the company to its assets. Based on the Pecking Order Theory, the greater the growth of companies' assets, the companies tend to use their own capital through Retained Earnings. This research is not in line with the research by (Nnadi, 2017), which shows a positive relationship between a firm's growth and capital structure.

The results of the test of sales growth variables in Table 4 (SGROW) for agricultural and mining companies that are in accordance with the sample criteria obtained the probability value of 0.8631 . The results of the test of sales growth variables for agricultural and mining companies that are in accordance with the sample criteria obtained the probability value of 0.8631. In addition, a coefficient of -0.000155 is also obtained. The probability value obtained is $0.8631>0.05$. It can be concluded that the sales growth variable does not affect the capital structure. Besides that, t-statistics <t-table is $-0.173071<1.99300$. So, based on this result, H3 is rejected, where sales growth does not affect the capital structure.

From the asset structure variable results, a probability value of 0.0857 was obtained. In addition, a coefficient of 0.000566 is also obtained. It can be seen that the probability value obtained by 0.0857>0.05. Therefore, it can be concluded that the Asset Structure variable does not affect the capital structure. In addition, t-statistics <t-table is $1.741227<1.99300$. So, based on this result, $\mathrm{H} 4$ is rejected, where the asset structure does not affect the capital structure.

According to the trade-off theory, the greater the number of assets, the greater the loan or debt that the company will get. The greater the value of the company's assets, the higher the possibility of investors to invest in the company. From the test results presented in table 5 (SGROW) above, the sales growth variable (SGROW) has a coefficient value of -1.305481 with a probability value of 0.4323 . The probability value is $0.4323>0.05$. Therefore, $\mathrm{Ha}$ is rejected, meaning that the sales growth variable does not have a significant effect on stock prices. Besides that, t-statistics <t-table is $-0.789390<1.99300$. This result shows that H5 is rejected, where sales growth does not affect stock prices.

Because high company growth has an impact on stock prices, when company growth is characterized by increasing sales, company managers will have a tendency to ask for more compensation in the form of various facilities. This does not provide added value to the company's shareholders, and further increases the agency problem between managers and shareholders.

From the results of the tests presented in table 5 (EPS), EPS variable significance value of 0.9397, and EPS variable coefficient value of 0.260476 were obtained. By using a significance level of $5 \%$ or 0.05 , it can be concluded that the EPS variable does not have a significant effect on stock prices. Besides that, the t-statistics <t-table is 0.075920 $<1.99300$. So, this result shows that H6 is rejected, where EPS does not affect the stock price.

From the results of the tests presented in table 5 (ASTRU), a significance value of 0.0413 with a negative coefficient of 1.281548 was obtained. Then, the probability value is $0.0413<0.05$, so, it can be concluded that the asset structure variable has a significant negative effect on stock prices (Ha is accepted). Besides that, t-statistics < $\mathrm{t}$-table is $2.076123>1.99300$. So, based on this result, H7 is accepted, where sales growth has a negative effect on stock prices. 
Ivena Gracial), Rosinta Ria Panggabean ${ }^{2)}$ Factors Affecting Capital Structure And Stock Prices Of Agricultural And Mining Companies

The greater the asset structure, the fixed assets owned by the company will increase, resulting in working capital and the ability of the company to meet the obligations of the company which will be due, so that the company will need capital from shares to fulfill it by reducing stock prices, so that many investors invest their assets. It can be concluded that the asset structure has an influence on stock prices.

\section{CONCLUSIONS AND RECOMMENDATIONS}

Based on the results of the research, the following conclusions can be drawn:

The results of the t-test conducted on the business risk variable on the capital structure show that HA1 is rejected. The results of the t-test carried out on the variable variability of asset growth on the capital structure show that HA2 is accepted. The results of the t-test performed on the sales growth variable on the capital structure show that HA3 is rejected. The results of the t-test performed on the asset structure variables on the capital structure show that HA4 is rejected. The results of the t-test carried out on the sales growth variable on stock prices show that HA5 is rejected. The results of the t-test conducted on EPS variables on stock prices show that HA6 is rejected. The results of the t-test carried out on asset structure variables on stock prices show that HA7 is accepted.

Further research should be conducted in a longer period of time so that it could better describe the effect of the actual data. Future research is expected to extend the study period to ten years. It is also possible to add primary data as supporting data to explore other factors that affect the capital structure and stock prices. It would be better if further research adds other variables, such as size or dividends.

\section{REFERENCE}

Alnajjar, M. I. M. (2015). Business Risk Impact on Capital Structure : A Case of Jordan Industrial Sector. Global Journal of Management and Business Reseach: C Finance. https://doi.org/10.1590/0034-7167.2016690304i

Amjed, S., \& Shah, S. M. A. (2016). No TitleThe Impact of Volatile Economic Conditions on Corporate Capital Structure Adjustment towards Dynamic Target in Pakistan. Pakistan Journal of Commerce \& Social Sciences, 10(2).

Badruzaman, J. (2017). Pengaruh Earning per Share terhadap harga saham. (Effect of Earnings per Share on share prices). Jurnal Akuntansi, 12(1), 101-110.

Baker, H. K., \& Martin, G. S. (2011). Capital Structure and Corporate Financing Decisions: Theory, Evidence, and Practice. In Capital Structure and Corporate Financing Decisions: Theory, Evidence, and Practice. https://doi.org/10.1002/9781118266250

Basuki, A. ., \& Prawoto, N. (2016). Analisis regresi dalam penelitian ekonomi \& bisnis. (Regression analysis in economic \& business research). Depok: Rajagrafindo Persada.

Coşkun, Y., Seven, Ü., Ertuğrul, H. M., \& Ulussever, T. (2017). Capital market and economic growth nexus: Evidence from Turkey. Central Bank Review. https://doi.org/10.1016/j.cbrev.2017.02.003 
Datu, C. V., \& Maredesa, D. (2017). PENGARUH DEVIDEND PER SHARE DAN EARNING PER SHARE TERHADAP HARGA SAHAM PADA PERUSAHAAN GO PUBLIC DI BURSA EFEK INDONESIA. Jurnal Riset Akuntansi Going Concern, 12(2).

Ferdiansyah, M. S., \& Isnurhadi. (2013). Faktor-Faktor yang Mempengaruhi Struktur Modal Pada Perusahaan Pertambangan yang Terdaftar di Bursa Efek Indonesia. Jurnal Manajemen \& Bisnis Sriwijaya, 11(2).

Ghazouani, T. (2013). The Capital Structure Through the Trade-Off Theory: Evidence from Tunisian Firm. International Journal of Economics and Financial Issues.

Indrajaya, G., Herlina, \& Setiadi, R. (2011). Pengaruh Struktur Aktiva, Ukuran Perusahaan, Tingkat Pertumbuhan, Profitabilitas, dan Risiko Bisnis Terhadap Stuktur Modal. Jurnal Ilmiah Akuntansi, 6(2).

Insiroh, L. (2014). PENGARUH PROFITABILITAS, UKURAN PERUSAHAAN, PERTUMBUHAN ASET, DAN STRUKTUR ASET TERHADAP STRUKTUR MODAL. Jurnal Ilmu Manajemen, 2(3), 979-990.

Kakilli Acaravci, S. (2015). The determinants of capital structure: Evidence from the Turkish manufacturing sector. International Journal of Economics and Financial Issues.

Kartika, A. (2009). FAKTOR - FAKTOR YANG MEMPENGARUHI STRUKTUR MODAL PADA PERUSAHAAN MANUFAKTUR YANG GO PUBLIC DI BEI. Dinamika Keuangan Dan Perbankan.

Kesuma, A. (2009). Analisis Faktor yang Mempengaruhi Struktur Modal Serta Pengaruhnya Terhadap Harga Saham Perusahaan Real Estate yang Go Public di Bursa Efek Indonesia. Jurnal Manajemen Dan Wirausaha. https://doi.org/10.9744/jmk.11.1.pp.38-45

Margaretha, F., \& Ramadhan, A. R. (2010). Faktor-Faktor Yang Mempengaruhi Struktur Modal Pada Industri Manufaktur Di Bursa Efek Indonesia. Jurnal Bisnis Dan Akuntansi.

Mohammed, D. (2012). Impact of Business Risk on Corporate Capital Structure of Publicly-Listed Nigerian Companies. IOSR Journal of Business and Management. https://doi.org/10.9790/487x-0520115

MYERS, S. C. (1984). The Capital Structure Puzzle. The Journal of Finance. https://doi.org/10.1111/j.1540-6261.1984.tb03646.x

Nnadi, M. (2017). Accounting Factors Affecting the Capital Structure in the Asian Economic Community. International Journal of Accounting Research. https://doi.org/10.4172/2472-114x.1000139

Nurmalasari, B. E. (2009). Pengembangan Aplikasi Alat Bantu Belajar Pengetahuan Atmosfer dan Hidrosfer Berbasis Multimedia. Universitas Atma Jaya: Skripsi, Yogyakarta.

Pahuja, A., \& Sahi, A. (2012). Factors Affecting Capital Structure Decisions : Empirical Evidence From Selected Indian Firms. International Journal of Marketing, Financial Services \& Management Reseach.

Purnamasari, D. (2015). The Effect of Changes in Return on Assets, Return on Equity, and Economic Value Added to the Stock Price Changes and Its Impact on Earnings Per Share. Research Journal of Finance and Accounting, 6(6), 80-90. 
PWC. (2017). Annual Report 2016/2017.

Ratih, D., Apriatni, E. P., \& Saryadi. (2013). Pengaruh EPS, PER, DER, ROE Terhadap Harga Saham pada Perusahaan Sektor Pertambangan yang Terdaftar di Bursa Efek Indonesia (BEI) Tahun 2010-2012. Journal of Social and Politic.

Sebayang, M. M., \& Putra, P. D. (2013). Pengaruh Karakteristik Perusahaan Terhadap Struktur Modal (studi empiris pada perusahaan manufaktur yang terdaftar di bursa efek indonesia periode 2006-2007). Jurnal Bina Akuntansi-IBBI, 19(2), 1858-3202.

Suryanta, B. (2014). An Evaluation of Indonesian Capital Market Co-integration with ASEAN 4 to Enter the ASEAN Capital Market Integration in Accordance to ASEAN Economic Community (AEC) 2020 Scheme: Should Indonesia Enter or Postpone? Indonesian Capital Market Review, 3(1). https://doi.org/10.21002/icmr.v3i1.3621

Wardana, A. D., \& Sudiartha, G. M. (2015). ENGARUH LIKUIDITAS, UKURAN PERUSAHAAN, RISIKO BISNIS DAN USIA PERUSAHAAN TERHADAP STRUKTUR MODAL PADA INDUSTRI PARIWISATA DI BURSA EFEK INDONESIA PERIODE 2010 - 2013. E-Jurnal Manajemen Unud, 4(6), 1701-1721.

Wimelda, L., \& Marlinah, A. (2013). Variabel-variabel yang mempengaruhi struktur modal pada perusahaan publik sektor non keuangan. (Variables that affect capital structure in public companies in the non-financial sector.). Media Bisnis, 5(3), 200-213.

Zhang, Y. (2010). The Product Category Effects on Capital Structure: Evidence from the SMEs of British Manufacturing Industry. International Journal of Business and Management. https://doi.org/10.5539/ijbm.v5n8p86 